\title{
SLCO2B1 Gene
}

National Cancer Institute

\section{Source}

National Cancer Institute. SLCO2B1 Gene. NCI Thesaurus. Code C105429.

This gene is involved in transport of organic anions. 